\title{
A designathon to co-create community- driven HIV self-testing services for Nigerian youth: findings from a participatory event
}

Kadija M. Tahlil ${ }^{1 \dagger}$, Chisom Obiezu-Umeh ${ }^{2 \dagger}$, Titi Gbajabiamila ${ }^{3 \dagger}$, Ucheoma Nwaozuru $^{2}$, David Oladele ${ }^{3}$, Adesola Z. Musa ${ }^{3}$, Ifeoma Idigbe ${ }^{3}$, Jane Okwuzu ${ }^{3}$, Agatha N. David ${ }^{3}$, Tajudeen A. Bamidele ${ }^{3}$, Collins O. Airhihenbuwa ${ }^{4}$, Nora E. Rosenberg ${ }^{5}$, Weiming Tang ${ }^{6}$, Jason J. Ong ${ }^{7,8}$, Donaldson F. Conserve ${ }^{9}$, Juliet Iwelunmor ${ }^{2 \dagger}$, Oliver Ezechi ${ }^{3 \dagger}$ and Joseph D. Tucker ${ }^{7,10^{*+}}$ (D)

\begin{abstract}
Background: Youth are at high risk for HIV, but are often left out of designing interventions, including those focused on adolescents. We organized a designathon for Nigerian youth to develop HIV self-testing (HIVST) strategies for potential implementation in their local communities. A designathon is a problem-focused event where participants work together over a short period to create and present solutions to a judging panel.
\end{abstract}

Methods: We organized a 72-h designathon for youth (14-24 years old) in Nigeria to design strategies to increase youth HIVST uptake. Proposals included details about HIVST kit service delivery, method of distribution, promotional strategy, and youth audience. Teams pitched their proposals to a diverse seven-member judging panel who scored proposals based on desirability, feasibility, potential impact and teamwork. We examined participants' sociodemographic characteristics and summarized themes from their HIVST proposals.

Results: Forty-two youth on 13 teams participated in the designathon. The median team size was 3 participants (IQR: 2-4). The median age was 22.5 years (IQR: 21-24), 66.7\% were male, 47.4\% completed tertiary education, and $50 \%$ lived in Lagos State. Themes from proposals included HIVST integration with other health services, digital marketing and distribution approaches, and engaging students. Judges identified seven teams with exceptional HIVST proposals and five teams were supported for further training.

Conclusions: The designathon provided a structured method for incorporating youth ideas into HIV service delivery. This approach could differentiate HIV services to be more youth-friendly in Nigeria and other settings.

Keywords: Designathon, Crowdsourcing, Youth, Human immunodeficiency virus (HIV), Self-test, Nigeria

\footnotetext{
* Correspondence: jdtucker@med.unc.edu

Kadija M. Tahlil, Chisom Obiezu-Umeh and Titi Gbajabiamila are Co-first

authors.

†Juliet Iwelunmor, Oliver Ezechi and Joseph D. Tucker are Co-senior authors.

${ }^{7}$ Faculty of Infectious and Tropical Diseases, London School of Hygiene and

Tropical Medicine, London, UK

${ }^{10}$ Department of Medicine, University of North Carolina at Chapel Hill, Chapel Hill, NC 27599, USA

Full list of author information is available at the end of the article
}

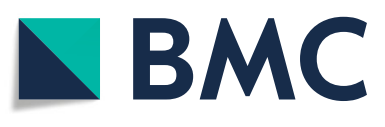

(c) The Author(s). 2021 Open Access This article is licensed under a Creative Commons Attribution 4.0 International License, which permits use, sharing, adaptation, distribution and reproduction in any medium or format, as long as you give appropriate credit to the original author(s) and the source, provide a link to the Creative Commons licence, and indicate if changes were made. The images or other third party material in this article are included in the article's Creative Commons licence, unless indicated otherwise in a credit line to the material. If material is not included in the article's Creative Commons licence and your intended use is not permitted by statutory regulation or exceeds the permitted use, you will need to obtain permission directly from the copyright holder. To view a copy of this licence, visit http://creativecommons.org/licenses/by/4.0/. The Creative Commons Public Domain Dedication waiver (http://creativecommons.org/publicdomain/zero/1.0/) applies to the data made available in this article, unless otherwise stated in a credit line to the data. 


\section{Background}

Youth (age14-24 years) account for an estimated onethird of all new HIV infections globally [1]. Although youth are disproportionately affected by HIV, their contributions to the development of interventions designed for them have often been limited and sometimes tokenistic [2-9]. Youth typically contribute to research as participants, key informants, and assistants [10, 11]. While some studies have expanded youth engagement in HIV research by creating youth advisory boards (YABs), the extent of meaningful engagement varies [12-21]. Providing youth with opportunities to create solutions to health problems that affect them can enhance program implementation and build capacity for youth as cocreators [10, 22].

One strategy to meaningfully engage youth is crowdsourcing, a practice in which solutions to a social problem are solicited from multiple individuals and then shared with the public [23]. It provides space for people with diverse backgrounds to work together and share their solutions with local communities. One form of crowdsourcing is a designathon, a problem-solving event, typically held over a few days, in which participants work together to create, design, and present their proposed solutions to a panel of judges [24]. Designathons have been previously used to solve problems in education, technology, and public health. Designathons foster multidisciplinary collaboration and can result in innovative solutions [24-26].

Responding to the need for youth engagement in HIV intervention design, we organized a designathon in Nigeria. The purpose was to develop ideas on how to promote HIV self-testing (HIVST) services among youth. This is part of the "Innovative Tools to Expand HIV Self-Testing" (ITEST) project, locally known as "4 Youth By Youth" [27]. HIVST is a process by which individuals collect their own oral fluid or blood specimen, conduct the HIV test, and interpret their results [28]. HIVST can help expand HIV testing services among those who have never tested before, such as many youth in Nigeria $[28,29]$. The objective of this paper is to describe the designathon, summarize the resulting HIVST proposals, and discuss public health implications.

\section{Methods}

The designathon was part of a multi-phase contest in which young people shared their ideas on how to promote HIVST among youth in Nigeria. This event was one component within the study's broader youth participatory process and we frame its processes and outcomes within this multi-phase context. We describe the initial contest (phase I) preceding the designathon and the training program (phase III) succeeding the designathon in supplementary materials (see Additional file 1: Supplement 1). We describe the designathon (phase II) below.

Between March 29-31, 2019, we hosted the designathon in Lagos, where 13 youth teams selected to participate designed strategies to increase youth HIVST. The expected deliverables included a prototype of teams' HIVST kit service delivery and a presentation of their idea to a panel of judges. We instructed teams to develop a community-based, youth-friendly model that would rely on modest payments. The price point was determined by earlier discrete choice experiments [30].

Day 1: We shared the purpose, rules, and expected deliverables of the contest to the teams. We familiarized participants with HIVST and briefed them about different testing kits in the Nigerian market. We scheduled panel discussions on challenges associated with standard HIV testing services and understanding the process of innovative problem-solving. Following the panel discussions, we asked participants to spend the remainder of the day in their teams to begin developing their HIVST proposals (Fig. 1).

Day 2: The teams participated in a presentation on how to effectively pitch their HIVST ideas. They continued working on their proposals, receiving tailored feedback (see Additional file 2: Supplement 2).

Day 3: We invited an independent panel of seven judges to listen to, review any support materials, ask questions and score teams' HIVST proposals. The judges' expertise included telecommunications, technology, product design, youth ambassadorship, and environmental sustainability. Each team, in turn, finalized their deliverables and presented their prototypes to the judges.

The judges evaluated proposals based on desirability, feasibility, impact, and teamwork. Desirability was defined as being appealing and meeting the needs of youth. Feasibility was defined as being easy to implement Nigeria. Impact was defined as having the potential to influence young people to self-test for HIV. Teamwork was defined as effectively working together. Each domain was scored on a three-point scale, with one being a low score, two being a medium score and three being a high score. The maximum score allotted to a team, from each judge, was 12 points. The top three teams were announced at the end of the designathon. The judges' scores for each team's HIVST proposal can be found in the supplementary materials (see Additional file 3: Supplement 3). We provided cash prizes to the top three teams: NGN 250,000 (\$694) for first place, NGN 150, 000 (\$416) for second place, and NGN 50,000 (\$138) for third place. We provided food, transportation, and accommodation to all participants. 


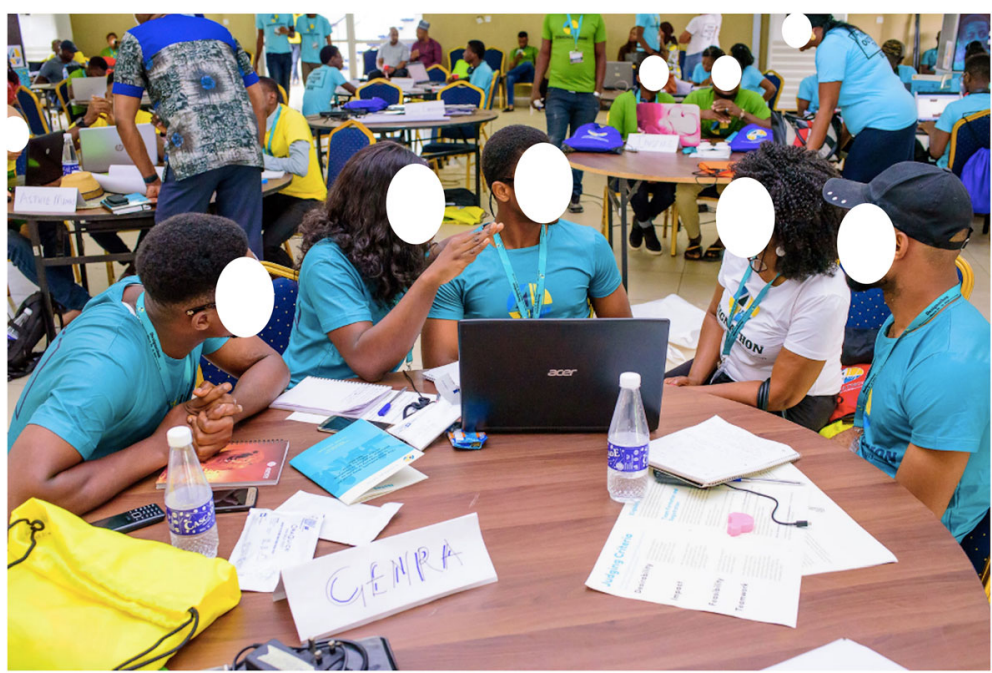

Fig. 1 Designathon team discussing their project and receiving mentorship from member of the contest advisory panel

\section{Data analysis}

We performed descriptive statistics to characterize demographic data of participants. We summarized teams' HIVST ideas with respect to their HIVST service delivery, method of distribution, promotional strategies, and youth audience.

\section{Results}

\section{Participant characteristics}

Forty-two young Nigerians were selected to participate in 13 teams (Table 1). The median team size was three participants (interquartile range: $2-4$ ). The median age was 22.5 years (interquartile range: $21-24$ ), $66.7 \%$ were male, $47.4 \%$ completed tertiary education, and $50 \%$ resided in Lagos State. Twenty-one (58.3\%) participants were students and four (11.1\%) were self-employed or entrepreneurs. Of 11 (30.6\%) employed participants, five were members of the National Youth Service Corps (NYSC), two were nurses, two were employees at a private company, one was a laboratory assistant, and one worked in human resources.

\section{Designathon pitches}

The primary goal of pitches by teams was to propose solutions on how to increase HIVST among youth in Nigeria (Table 2). Their ideas varied across the HIVST service delivery, method of distribution, promotional strategies, and youth audience.

\section{HIVST service delivery}

Five teams proposed delivering HIVST kits with other STI testing or health products. Three of these teams focused on creating a bundle product that combined HIVS $\mathrm{T}$ with self-care products (e.g. condoms, lubricants, panty liners), one of which finished in third place. Of the
Table 1 Characteristics of participants at the designathon: Nigeria $2019(N=42)$

\begin{tabular}{|c|c|c|}
\hline & $\mathbf{n}$ & $\%$ \\
\hline \multicolumn{3}{|l|}{ Age (Years) } \\
\hline $18-21$ & 14 & 33.3 \\
\hline $22-24$ & 28 & 66.7 \\
\hline \multicolumn{3}{|l|}{ Gender } \\
\hline Female & 14 & 33.3 \\
\hline Male & 28 & 66.7 \\
\hline \multicolumn{3}{|l|}{ Location (State) } \\
\hline Abuja & 2 & 4.8 \\
\hline Cross River & 4 & 9.5 \\
\hline Edo & 1 & 2.4 \\
\hline Enugu & 5 & 11.9 \\
\hline Kwara & 1 & 2.4 \\
\hline Lagos & 21 & 50 \\
\hline Ondo & 2 & 4.8 \\
\hline Osun & 1 & 2.4 \\
\hline Oyo & 4 & 9.5 \\
\hline Rivers & 1 & 2.4 \\
\hline \multicolumn{3}{|l|}{ Highest Level of Education } \\
\hline Senior Secondary & 15 & 39.5 \\
\hline Some Tertiary & 5 & 13.2 \\
\hline Tertiary & 18 & 47.4 \\
\hline Missing & 4 & \\
\hline \multicolumn{3}{|l|}{ Occupation } \\
\hline Employed & 11 & 30.6 \\
\hline Self Employed/Entrepreneur & 4 & 11.1 \\
\hline Student & 21 & 58.3 \\
\hline Missing & 6 & \\
\hline
\end{tabular}


Table 2 HIV self-testing (HIVST) services proposed by the thirteen teams at the designathon: Nigeria 2019

\begin{tabular}{|c|c|c|c|c|c|c|c|}
\hline Rank & $\begin{array}{l}\text { Team } \\
\text { Characteristics }\end{array}$ & Members & State & HIVST Project Proposal & Digital Approaches & $\begin{array}{l}\text { Youth } \\
\text { Audience }\end{array}$ & Score $^{b}$ \\
\hline 1 & $\begin{array}{l}\text { Public Health } \\
\text { Professionals }\end{array}$ & 2 & Oyo & $\begin{array}{l}\text { Develop a website that will allow individuals to } \\
\text { purchase HIVST and other STI kits. The website will } \\
\text { provide access to trained volunteers, instructions on } \\
\text { how to self-test, and information on post-testing ser- } \\
\text { vices. This team will utilize peer-to-peer referral to in- } \\
\text { crease distribution of kits. }\end{array}$ & None specified. & $\begin{array}{l}\text { Rural } \\
\text { adolescent } \\
\text { girls NYSC } \\
\text { members }\end{array}$ & 71 \\
\hline 2 & $\begin{array}{l}\text { Tertiary } \\
\text { Students }\end{array}$ & 4 & Enugu & $\begin{array}{l}\text { HIVST kits will be distributed through various offline } \\
\text { retailers and social media. The kits will be equipped } \\
\text { with a code that individuals will need to gain access } \\
\text { to the team' social media app. The social media app } \\
\text { wil allow individuals to report their results and find } \\
\text { their nearest youth-friendly clinic. }\end{array}$ & $\begin{array}{l}\text { Create a social media } \\
\text { app for young people } \\
\text { who have purchased } \\
\text { HIVST kits. } \\
\text { Conduct an online } \\
\text { marketing campaign } \\
\text { through social media. } \\
\text { Distribute kits through } \\
\text { WhatsApp, Facebook, } \\
\text { Twitter and Instagram. }\end{array}$ & $\begin{array}{l}\text { Tertiary } \\
\text { students } \\
\text { Young } \\
\text { people on } \\
\text { social media }\end{array}$ & 70 \\
\hline $3^{a}$ & $\begin{array}{l}\text { NYSC Members } \\
\text { Entrepreneur }\end{array}$ & 5 & Lagos & $\begin{array}{l}\text { HIVST kits will be packaged with self care products } \\
\text { (condoms, sanitary pads, soaps). Young people will } \\
\text { buy the kit online, at a pharmacy, gym or retail } \\
\text { outlet. Upon completion of the self-test, individuals } \\
\text { can submit their results to a study phone number } \\
\text { and receive post-test services. }\end{array}$ & $\begin{array}{l}\text { Conduct an online } \\
\text { marketing campaign } \\
\text { through social media. }\end{array}$ & & 62 \\
\hline 4 & $\begin{array}{l}\text { Tertiary } \\
\text { Students }\end{array}$ & 5 & Lagos & $\begin{array}{l}\text { HIVST kits will be packaged with self care products } \\
\text { (condoms and lubricants). The kits will be distributed } \\
\text { through online and offline platforms. In additon to } \\
\text { online marketing, the team will rely on peer-to-peer } \\
\text { referral to increase distribution of kits. }\end{array}$ & $\begin{array}{l}\text { Conduct an online } \\
\text { marketing campaign } \\
\text { through social media. }\end{array}$ & $\begin{array}{l}\text { Out-of- } \\
\text { school AYPs } \\
\text { FSWs } \\
\text { MSM }\end{array}$ & 63 \\
\hline 5 & $\begin{array}{l}\text { Tertiary } \\
\text { Students }\end{array}$ & 2 & Lagos & $\begin{array}{l}\text { Develop a mobile/web app that will allow individuals } \\
\text { to purchase HIVST kits, record their test results, obtain } \\
\text { information on HIV, and access post-testing services. } \\
\text { The team will utilize peer-to-peer referral to increase } \\
\text { distribution of kits. }\end{array}$ & $\begin{array}{l}\text { Conduct an online } \\
\text { marketing campaign } \\
\text { through social media. }\end{array}$ & $\begin{array}{l}\text { Secondary } \\
\text { and tertiary } \\
\text { students }\end{array}$ & 61 \\
\hline 6 & $\begin{array}{l}\text { Tertiary } \\
\text { Students }\end{array}$ & 2 & Ondo & $\begin{array}{l}\text { HIVST kits will be packaged with nutritional } \\
\text { supplements. Students will buy the kits at } \\
\text { pharmacies, or through campus ambassadors. Upon } \\
\text { completion of the self-test, students can access off- } \\
\text { line or online post-test services. }\end{array}$ & $\begin{array}{l}\text { Conduct an online } \\
\text { marketing campaign } \\
\text { through social media. }\end{array}$ & $\begin{array}{l}\text { Tertiary } \\
\text { students }\end{array}$ & 51 \\
\hline 7 & $\begin{array}{l}\text { Tertiary } \\
\text { Students }\end{array}$ & 2 & Oуо & $\begin{array}{l}\text { HIVST kits will distributed through recharge card } \\
\text { vendors and SIM registration centers. }\end{array}$ & $\begin{array}{l}\text { Conduct an online } \\
\text { marketing campaign } \\
\text { through social media. }\end{array}$ & & 51 \\
\hline 8 & $\begin{array}{l}\text { Tertiary } \\
\text { Students } \\
\text { Human } \\
\text { Resources } \\
\text { Professional }\end{array}$ & 3 & Lagos & $\begin{array}{l}\text { HIVST kits will be distributed through vending } \\
\text { machines. Young people will provide their phone } \\
\text { numbers during the purchase and receive a link to } \\
\text { download the team's app, which will give them } \\
\text { access to various health services. }\end{array}$ & None specified. & $\begin{array}{l}\text { Tertiary } \\
\text { students }\end{array}$ & 49 \\
\hline 9 & $\begin{array}{l}\text { Tertiary } \\
\text { Students } \\
\text { Entrepreneur }\end{array}$ & 5 & $\begin{array}{l}\text { Edo } \\
\text { Lagos }\end{array}$ & $\begin{array}{l}\text { HIVST and other STI kits will be packaged with self } \\
\text { care products (condoms, sanitary pads, soaps). The } \\
\text { kits will be equipped with a code that individuals can } \\
\text { use to text the team for follow-up. }\end{array}$ & None specified. & & 47 \\
\hline 10 & NYSC Members & 2 & Lagos & $\begin{array}{l}\text { Develop a website that will direct individuals to their } \\
\text { nearest health facility to collect HIVST kits and receive } \\
\text { pre-counseling services. The kits will contain an in- } \\
\text { struction manual on how to use the kit and informa- } \\
\text { tion on the appropriate post-testing services. }\end{array}$ & None specified. & $\begin{array}{l}\text { Tertiary } \\
\text { students } \\
\text { NYSC } \\
\text { members }\end{array}$ & 47 \\
\hline 11 & $\begin{array}{l}\text { Tertiary } \\
\text { Student } \\
\text { Nurses } \\
\text { Laboratory } \\
\text { Teaching } \\
\text { Assistant }\end{array}$ & 4 & $\begin{array}{l}\text { Kwara } \\
\text { Osun } \\
\text { Enugu } \\
\text { Rivers }\end{array}$ & $\begin{array}{l}\text { Develop a mobile app that will allow young people } \\
\text { to purchase HIVST and other STI kits. Individuals will } \\
\text { use the mobile app to access post-test counseling } \\
\text { services, get information about HIV risk-reduction } \\
\text { strategies, and be referred for confirmatory testing } \\
\text { and care. }\end{array}$ & None specified. & & 47 \\
\hline 12 & Private & 2 & Abuja & Develop a mobile app that will allow Individuals to & None specified. & & 45 \\
\hline
\end{tabular}


Table 2 HIV self-testing (HIVST) services proposed by the thirteen teams at the designathon: Nigeria 2019 (Continued)

\begin{tabular}{|c|c|c|c|c|c|c|c|}
\hline Rank & $\begin{array}{l}\text { Team } \\
\text { Characteristics }\end{array}$ & Members & State & HIVST Project Proposal & Digital Approaches & $\begin{array}{l}\text { Youth } \\
\text { Audience }\end{array}$ & Score $^{\mathrm{b}}$ \\
\hline & $\begin{array}{l}\text { Company } \\
\text { Employees }\end{array}$ & & FCT & $\begin{array}{l}\text { play an interactive game. Throughout the game, } \\
\text { individuals will be provided with information about } \\
\text { HIVST. At the end of the game, individuals will be } \\
\text { shown a toll-free number they can call to acquire } \\
\text { HIVST kits and information about HIV and other STDs. }\end{array}$ & & & \\
\hline 13 & $\begin{array}{l}\text { Tertiary } \\
\text { Students } \\
\text { Self-employed } \\
\text { Professionals }\end{array}$ & 4 & $\begin{array}{l}\text { Cross } \\
\text { River }\end{array}$ & $\begin{array}{l}\text { Develop a website that will direct individuals to their } \\
\text { nearest health facility to collect HIVST kits. Individuals } \\
\text { with no internet access can use their mobile phones } \\
\text { to dial a short code and get information about } \\
\text { where to obtain HIVST kits. }\end{array}$ & $\begin{array}{l}\text { Conduct an online } \\
\text { marketing campaign } \\
\text { through social media. }\end{array}$ & & 42 \\
\hline
\end{tabular}

Tertiary students in Nigeria are individuals who attend universities, polytechnics, monotechnics, or colleges of education

HIVST HIV self-testing, NYSC National Youth Service Corps, AYPs Adolescent and Young People, FSWs Female Sex Workers, MSM Men who have sex with men

${ }^{a}$ This team scored lower than the fourth place team, but the judges deliberated and decided to elevate this team to third place because their concept was more

attractive and could better appeal to young people

${ }^{\mathrm{b}} \mathrm{S}$ cores were rounded to the nearest whole numbe

remaining two teams, one pitched selling two HIVST kits in one set to reduce the purchasing cost for young people and another proposed complementing HIVST with nutritional supplements.

\section{Method of distribution}

Six teams proposed an online platform to sell kits. These online platforms included websites, online retail stores, and mobile phone applications. Among the six teams with an online platform, three also had an offline distribution strategy, such as placing their kits at pharmacies, retail outlets, or gyms to reach young people who may not have access to phones or the internet. Six teams proposed to distribute their kits solely offline. Among these six teams, two developed creative methods to distribute their kits. One team proposed to stock vending machines with HIVST kits in areas with more youth and another team would partner with mobile phone card vendors.

\section{Promotional strategies}

Seven teams planned to use social media (WhatsApp, Facebook, Instagram, and Twitter) to conduct online marketing campaigns for their kits. One team, which finished in second place, developed their own social media application where youth could report their test results and find post-test HIV services. Three teams described a peer referral system to enhance HIVST uptake, of which two incentivized youth for peer referrals.

\section{Youth audience}

Five teams planned to focus on youth in school. Four teams focused on tertiary students and one team focused on both secondary and tertiary students. One team planned to engage hard-to-reach populations such as out-of-school youth, female sex workers, and men who have sex with men. One team proposed to recruit rural adolescent girls and members of the National Youth
Service Corps (NYSC), a mandatory service program for Nigerian youth. This team, which finished in first place, proposed leveraging youth service networks to distribute kits and encourage HIVST.

Designathon proposals shared the following characteristics: educating youth on their health status and where to obtain appropriate services; offering care relevant to the needs of youth; and providing the opportunity for youth to participate in health service delivery. Furthermore, the teams provided youth with alternatives to clinical settings to access HIV and services. Moreover, all teams underscored the importance of maintaining young peoples' rights to privacy and confidentiality. The teams also proposed to partner with institutions (e.g. schools, local community centers) where youth frequent to advertise and distribute their kits.

\section{Discussion}

We organized a designathon in which we crowdsourced ideas on how to increase HIVST among Nigerian youth. This designathon provided an opportunity for young Nigerians to collaborate and develop strategies. We extend the literature by using a designathon methodology, allowing robust input from youth, and providing structured feedback and mentorship.

The designathon generated proposals that were determined by a judging panel to be potentially feasible, desirable, and impactful. The participants' diverse backgrounds and expertise may have helped in the development of promising proposals. Youth with different perspectives can draw from their experiences to develop potentially feasible interventions. This insight is consistent with a previous designathon in the United States that brought together diverse individuals [25]. The high quality of submissions may also have been related to their knowledge of local health services and youth preferences [22].

The designathon engaged local youth and allowed them to meaningfully contribute. Youth participants led 
the design of HIVST interventions, which is rare in health research [31, 32]. There are implications for allowing youth to design solutions to health problems. Although the designathon was open to youth age 14-24 years, individuals selected to participate were all 18-24 years. Thus, older adolescents were more successful in presenting promising HIVST ideas. Moreover, participants were aware selected finalists would be allowed to not only design an HIVST strategy but implement it in their local areas. It is possible that this designathon encouraged a sense of community ownership among participants, which has been observed in a previous HIVrelated designathon [24].

Several proposals integrated HIVST with sexual/reproductive health services. This finding is consistent with larger literature underlining the importance of integrating HIV testing services and sexual/reproductive health services [33-38]. In these other contexts, HIV testing service had been embedded within family planning, STI testing, and sexual health counseling. These studies demonstrate the integration of HIV services with other health services increases testing acceptability and health service use, improving the quality of care [33-37]. Given that many youth at risk for HIV also need other services, integrated HIV care may be an effective approach to reach young people.

Our study has several limitations. First, the judges selected HIVST proposals that had the potential to be feasible, desirable, and impactful. Judges did not have outcome data on these domains when judging, but pilots are now underway. Second, designathons are typically held over a few days, much shorter than would allow them to develop a comprehensive HIVST plan. However, following our designathon, selected finalists were then invited to a four-week training program to build research and entrepreneurial skills and implement and manage their programs. Finally, the designathon is resource-intensive, which can be challenging in resource-limited settings. To minimize costs, we leveraged local resources, such as staffing from the Nigerian implementing team and passionate volunteers to serve as mentors.

The designathon contained novel features, which has implications for public health research and policy. First, this event allowed youth to lead in the development of interventions that could benefit them, which is rare in many HIV programs for youth in low and middleincome countries. Designathons may provide an opportunity for youth to take health ownership and lead health research. Furthermore, results from these teams' proposals can help HIV testing services be more responsive to the unique needs of youth. Further implementation science is needed to evaluate the effectiveness of the proposed ideas.

\section{Conclusions}

We described the processes and outcomes of the first health-related designathon in Nigeria that focused on improving HIVST among youth. Youth-led development of HIVST strategies offers promising solutions to expand HIVST among young people in Nigeria.

\section{Abbreviations}

AIDS: Acquired Immunodeficiency Syndrome; HIV: Human Immunodeficiency Virus; HIVST: HIV Self-testing; ITEST: Innovative Tools to Expand HIV SelfTesting; NGN: Nigerian Naira; NYSC: National Youth Service Corps;

STI: Sexually Transmitted Infection; YAB: Youth Advisory Board

\section{Supplementary Information}

The online version contains supplementary material available at https://doi. org/10.1186/s12879-021-06212-6.

Additional file 1: Supplement 1. Timeline of study events: Nigeria 2019.

Additional file 2: Supplement 2. Photographs from the designathon: Nigeria 2019.

Additional file 3: Supplement 3. Judges' scores for all teams at the designathon: Nigeria 2019*.

\section{Acknowledgements}

The authors thank the Nigerian Institute of Medical Research, Lagos State AIDS Control Agency, Lagos State Ministry of Education, Steering Committee of Social Entrepreneurship to Spur Health, PinPoint Media, 4 Youth By Youth ambassadors, the program officers and members of the Prevention and Treatment through a Comprehensive Care Continuum for HIV-affected Adolescents in Resource Constrained Settings Consortium, and designathon judges for their help in planning and implementing the designathon.

\section{Authors' contributions}

KMT: data analysis, writing the manuscript. CO, TG: project administration, data collection and analysis, writing the manuscript. UN: project administration, data collection, reviewing and editing the manuscript. DO, AZM, II, JO, AND, TAB: project administration, reviewing and editing the manuscript. COA, NER, WT, JJO, DFC: reviewing and editing the manuscript. JI, OE, JDT: project conceptualization and administration, reviewing and editing the manuscript, overall oversight. All authors read and approved the final manuscript.

\section{Funding}

This work was made possible by the Eunice Kennedy Shriver National Institute of Child Health and Human Development (NICHD) Grant number: UG3HD096929, UH3HD096929 and NIAID K24AI143471. The funders played no role in the design of the study and collection, analysis, interpretation of data and in writing the manuscript.

\section{Availability of data and materials}

The datasets used and/or analyzed during the current study are available from the corresponding author on reasonable request.

\section{Declarations}

Ethics approval and consent to participate

We obtained ethical approval from the institutional review boards of Saint Louis University (St. Louis, MO), University of North Carolina at Chapel Hill (Chapel Hill, NC), and the Nigerian Institute of Medical Research (Lagos, Nigeria). We received a waiver of written informed consent for the designathon and used an online consent form to obtain informed consent. All participants provided consent to participate. The age of research consent in Nigeria is 14 years old. 


\section{Consent for publication}

We obtained verbal consent from designathon participants to publish photographs of their participation in the event. We used an online consent form to obtain informed consent from participants. Before entering the online study materials, participants were presented with contest terms and conditions that included the following statement: "by continuing any use of this website and by submitting an application to the HIV self-testing designathon, you expressly consent to the official rules and terms." Participants had the option to click "I agree" or "I disagree" to acknowledge that they had read and understood the informed consent, and either agree or disagree to participate in the study.

\section{Competing interests}

The authors declare that they have no competing interests.

\section{Author details}

'Department of Epidemiology, University of North Carolina at Chapel Hill, Chapel Hill, NC, USA. ${ }^{2}$ Department of Behavioral Science and Health Education, Saint Louis University, Saint Louis, MO, USA. ${ }^{3}$ Nigerian Institute of Medical Research, Lagos, Nigeria. ${ }^{4}$ School of Public Health, Georgia State University, Atlanta, GA, USA. ${ }^{5}$ Department of Health Behavior, University of North Carolina at Chapel Hill, Chapel Hill, NC, USA. ${ }^{6}$ Dermatology Hospital, Southern Medical University, Guangzhou, China. ${ }^{7}$ Faculty of Infectious and Tropical Diseases, London School of Hygiene and Tropical Medicine, London, UK. ${ }^{8}$ Central Clinical School, Monash University, Melbourne, Australia. ${ }^{9}$ Department of Health Promotion, Education, and Behavior, Arnold School of Public Health, The University of South Carolina, Columbia, SC, USA.

${ }^{10}$ Department of Medicine, University of North Carolina at Chapel Hill, Chapel Hill, NC 27599, USA.

\section{Received: 1 June 2020 Accepted: 19 May 2021}

\section{Published online: 31 May 2021}

\section{References}

1. United Nations Children's Fund. Towards an AIDS-free generation-children and AIDS: sixth stocktaking report. New York: UNICEF; 2013.

2. Denison JA, Pettifor A, Mofenson LM, Kasedde S, Marcus R, Konayuma KJ, et al. Youth engagement in developing an implementation science research agenda on adolescent HIV testing and care linkages in sub-Saharan Africa. AIDS. 2017;31(Suppl 3):S195-201. https://doi.org/10.1097/QAD. 0000000000001509 .

3. Oliveras C, Cluver L, Bernays S, Armstrong A. Nothing about us without RIGHTS-meaningful engagement of children and youth: from research prioritization to clinical trials, implementation science, and policy. J Acquir Immune Defic Syndr. 2018;78(Suppl 1):S27-31. https://doi.org/10.1097/QAI. 0000000000001746.

4. McLaughlin K. Empowerment: a critique. New York: Routledge; 2016. https:// doi.org/10.4324/9781315744339.

5. Arnstein SR. A ladder of citizen participation. J Am Inst Plann. 1969;35(4): 216-24. https://doi.org/10.1080/01944366908977225.

6. Yang F, Janamnuaysook R, Boyd MA, Phanuphak N, Tucker JD. Key populations and power: people-centred social innovation in Asian HIV services. Lancet HIV. 2020;7(1):e69-74. https://doi.org/10.1016/S2352-3018(1 9) $30347-9$

7. Hart RA. Children's Participation: From tokenism to citizenship. Innocenti Essay no. 4; 1992.

8. O'Donoghue J, Kirshner B, McLaughlin M. Introduction: moving youth participation forward. In: New directions for youth development: theory, practice and research, no. 96; 2003. p. 15-26.

9. Gleeson HS, Oliveras Rodriguez CA, Hatane L, Hart D. Ending AIDS by 2030: the importance of an interlinked approach and meaningful youth leadership. J Int AIDS Soc. 2018;21 Suppl 1(Suppl Suppl 1):e25061. https:// doi.org/10.1002/jia2.25061.

10. Kirshner B, O'Donoghue J, McLaughlin M. Youth-adult research collaborations: bringing youth voice to the research process. In: Organized activities as contexts of development: extracurricular activities, after-school and community programs. Erlbaum: Lawrence; 2005. p. 1531-156.

11. Hawke LD, Relihan J, Miller J, McCann E, Rong J, Darnay K, et al. Engaging youth in research planning, design and execution: practical recommendations for researchers. Health Expect. 2018;21(6):944-9. https:// doi.org/10.1111/hex.12795.
12. Underwood C, Hachonda H, Serlemitsos E, Bharath-Kumar U. Reducing the risk of HIV transmission among adolescents in Zambia: Psychosocial and behavioral correlates of viewing a risk-reduction media campaign. J Adolesc Health. 2006;38(1). https://doi.org/10.1016/j.jadohealth.2004.09.022.

13. Lawrence JSS, Seloilwe E, Magowe M, Dithole K, Kgosikwena B, Kokoro E, et al. Cross-cultural adaptation of an adolescent HIV prevention program: social validation of social contexts and behavior among Botswana adolescents. AIDS Educ Prev. 2013;25(4):269-86. https://doi.org/10.1521/aea p.2013.25.4.269.

14. Wilson PA, Cherenack EM, Jadwin-Cakmak L, Harper GW. Adolescent medicine trials network for HIV/AIDS interventions. Selection and evaluation of Media for Behavioral Health Interventions Employing Critical Media Analysis. Health Promot Pract. 2017;19(1):145-56. https://doi.org/10.1177/1 524839917711384

15. Hussen SA, Jones M, Moore S, Hood J, Smith JC, Camacho-Gonzalez A, et al. Brothers building brothers by breaking barriers: development of a resiliencebuilding social capital intervention for young black gay and bisexual men living with HIV. AIDS Care. 2018;30(sup4):51-8. https://doi.org/10.1080/0954 0121.2018.1527007.

16. Rennie S, Groves AK, Hallfors DD, Iritani BJ, Odongo FS, Luseno WK. The significance of benefit perceptions for the ethics of HIV research involving adolescents in Kenya. J Empir Res Hum Res Ethics. 2017;12(4):269-79. https://doi.org/10.1177/1556264617721556.

17. Groves AK, Hallfors DD, Iritani BJ, Rennie S, Odongo FS, Kwaro D, et al. "I think the parent should be there because no one was born alone": Kenyan adolescents' perspectives on parental involvement in HIV research. Afr J AIDS Res. 2018;17(3):227-39. https://doi.org/10.2989/16085906.2018.1504805.

18. Reisner SL, Jadwin-Cakmak L, White Hughto JM, Martinez M, Salomon L, Harper GW. Characterizing the HIV prevention and care continua in a sample of transgender youth in the U.S. AIDS Behav. 2017;21(12):3312-27. https://doi.org/10.1007/s10461-017-1938-8.

19. Hightow-Weidman L, Muessig K, Knudtson K, Srivatsa M, Lawrence E, LeGrand S, et al. A Gamified Smartphone App to Support Engagement in Care and Medication Adherence for HIV-Positive Young Men Who Have Sex With Men (AllyQuest): Development and Pilot Study. JMIR Public Health Surveill. 2018;4(2):e34. https://doi.org/10.2196/publichealth.8923 Published 2018 Apr 30.

20. Jadwin-Cakmak L, Reisner SL, Hughto JMW, Salomon L, Martinez M, Popoff E, et al. HIV prevention and HIV care among transgender and gender diverse youth: design and implementation of a multisite mixed-methods study protocol in the U.S. BMC Public Health. 2019;19(1):1531. https://doi. org/10.1186/s12889-019-7605-4 Published 2019 Nov 15.

21. Wootton AR, Legnitto DA, Gruber VA, Dawson-Rose C, Neilands TB, Johnson $\mathrm{MO}$, et al. Telehealth and texting intervention to improve HIV care engagement, mental health and substance use outcomes in youth living with HIV: a pilot feasibility and acceptability study protocol. BMJ Open. 2019;9(7):e028522. https://doi.org/10.1136/bmjopen-2018-028522 Published 2019 Jul 16.

22. Powers JL, Tiffany JS. Engaging youth in participatory research and evaluation. J Public Health Manage Pract. 2006;12:579-87. https://doi.org/1 0.1097/00124784-200611001-00015.

23. World Health Organization (WHO). Crowdsourcing in health and health research: a practical guide. Geneva: WHO; 2018.

24. Tucker JD, Tang W, Li H, Chuncheng L, Rong F, Songyuan T, et al. Crowdsourcing designathon: a new model for multisectoral collaboration. BMJ Innovations. 2018;4(2):46-50. https://doi.org/10.1136/bmjinnov-2017000216.

25. Artiles J, Wallace D. Borrowing from hackathons: overnight designathons as a template for creative idea hubs in the space of hands-on learning, digital learning, and systems re-thinking. Cartagena: World Engineering Education Forum; 2013. p. 1-8.

26. Holtzblatt K, Marsden N. Designathon to support women in tech. In: Extended abstracts of the $2018 \mathrm{CHI}$ conference on human factors in computing systems - CHI 18; 2018. https://doi.org/10.1145/3170427.3185361.

27. Iwelunmor J, Ezechi O, Obiezu-Umeh C, Gbajabiamila T, Nwaozuru U, Oladele $\mathrm{D}$, et al. The 4 youth by youth HIV self-testing contest: $\mathrm{A}$ crowdsourced contest to promote HIV self-testing among young people in Nigeria. In: [Abstract TUPEC471] 10th IAS Conference on HIV Science (IAS 2019). Mexico City: International AIDS Society; 2019.

28. World Health Organization (WHO). Guidelines on HIV self-testing and partner notification. Geneva: WHO; 2016. 
29. Oginni A, Obianwu O, Adebajo S. Socio-demographic factors associated with uptake of HIV counseling and testing (HCT) among Nigerian youth. AIDS Res Hum Retrovir. 2014;30(S1):A113. https://doi.org/10.1089/aid.2014. 5216.abstract.

30. Nwaozuru U, Iwelunmor J, Ong JJ, Salah S, Obiezu-Umeh C, Ezechi O, et al. Preferences for HIV testing services among young people in Nigeria. BMC Health Serv Res. 2019;19(1):1003. https://doi.org/10.1186/s12913-019-4847-x Published 2019 Dec 27.

31. Reed SJ, Miller RL. The adolescent medicine trials network for HIV/AIDS interventions. The benefits of youth engagement in HIV-preventive structural change interventions. Youth Soc. 2014;46(4):529-47. https://doi. org/10.1177/0044118X12443372.

32. Wong NT, Zimmerman MA, Parker EA. A typology of youth participation and empowerment for child and adolescent health promotion. Am J Community Psychol. 2010;46(1-2):100-14. https://doi.org/10.1007/s10464-01 0-9330-0.

33. Rosenberg NE, Bhushan NL, Vansia D, Phanga T, Maseko B, Nthani T, et al. Comparing youth-friendly health services to the standard of care through "girl power-Malawi": a quasi-experimental cohort study. J Acquir Immune Defic Syndr. 2018;79(4):458-66. https://doi.org/10.1097/QAl.0000000000001 830.

34. Buzi RS, Madanay FL, Smith PB. Integrating routine HIV testing into family planning clinics that treat adolescents and young adults. Public Health Rep. 2016;131 Suppl 1(Suppl 1):130-8. https://doi.org/10.1177/0033354916131 OS115.

35. Campos-Outcalt D, Mickey T, Weisbuch J, Jones R. Integrating routine HIV testing into a public health STD clinic. Public Health Rep. 2006;121(2):17580. https://doi.org/10.1177/003335490612100212.

36. Dukers-Muijrers NH, Somers C, Hoebe CJ, Lowe SH, Niekamp AM, Oude Lashof A, et al. Improving sexual health for HIV patients by providing a combination of integrated public health and hospital care services; a onegroup pre- and post test intervention comparison. BMC Public Health. 2012; 12:1118. https://doi.org/10.1186/1471-2458-12-1118 Published 2012 Dec 27.

37. Coyne KM, Hawkins F, Desmond N. Sexual and reproductive health in HIVpositive women: a dedicated clinic improves service. Int J STD AIDS. 2007: 18(6):420-1. https://doi.org/10.1258/095646207781024766.

38. Nwaozuru U, Gbajabiamila T, Obiezu-Umeh C, Uzoaru F, Mason S, Tahlil K, et al. An innovation bootcamp model to develop HIV self-testing social enterprise among young people in Nigeria: a youth participatory design approach. Lancet Glob Health. 2020;8(Suppl 1):S12. https://doi.org/10.1016/ S2214-109X(20)30153-4.

\section{Publisher's Note}

Springer Nature remains neutral with regard to jurisdictional claims in published maps and institutional affiliations.

Ready to submit your research? Choose BMC and benefit from:

- fast, convenient online submission

- thorough peer review by experienced researchers in your field

- rapid publication on acceptance

- support for research data, including large and complex data types

- gold Open Access which fosters wider collaboration and increased citations

- maximum visibility for your research: over $100 \mathrm{M}$ website views per year

At BMC, research is always in progress.

Learn more biomedcentral.com/submissions 


\section{University Library}

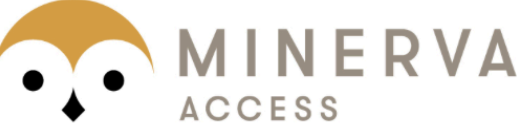

A gateway to Melbourne's research publications

Minerva Access is the Institutional Repository of The University of Melbourne

\section{Author/s:}

Tahlil, KM;Obiezu-Umeh, C;Gbajabiamila, T;Nwaozuru, U;Oladele, D;Musa, AZ;Idigbe, I;Okwuzu, J;David, AN;Bamidele, TA;Airhihenbuwa, CO;Rosenberg, NE;Tang, W;Ong, JJ;Conserve, DF;Iwelunmor, J;Ezechi, O;Tucker, JD

Title:

A designathon to co-create community-driven HIV self-testing services for Nigerian youth: findings from a participatory event

\section{Date:}

2021-05-31

\section{Citation:}

Tahlil, K. M., Obiezu-Umeh, C., Gbajabiamila, T., Nwaozuru, U., Oladele, D., Musa, A. Z., Idigbe, I., Okwuzu, J., David, A. N., Bamidele, T. A., Airhihenbuwa, C. O., Rosenberg, N. E., Tang, W., Ong, J. J., Conserve, D. F., Iwelunmor, J., Ezechi, O. \& Tucker, J. D. (2021). A designathon to co-create community-driven HIV self-testing services for Nigerian youth: findings from a participatory event. BMC INFECTIOUS DISEASES, 21 (1), https:// doi.org/10.1186/s12879-021-06212-6.

Persistent Link:

http://hdl.handle.net/11343/278402

License:

CC BY 